811.163.41'38'35

821.111(73).08 Хобан P.

https://doi.org/10.18485/sj.2020.25.1.28

ИВАНА Б. ПАЛИБРК

Универзитет у Крагујевцу

Филолошко-уметнички факултет
Оригинални научни рад

Примљен: 15. 10. 2019.

Прихваћен: 15. 01. 2020.

\title{
ЕНГЛЕСКИ ПО ВУКУ? - ГРАФОСТИЛЕМСКИ АСПЕКТ РОМАНА РИДЛИ ВОКЕР
}

Радом се представља графолошки ниво у роману „Ридли Вокер” аутора Расла Хоубна. Пишчева предложена правописна форма којом се дело издваја у савременој англистичкој књижевности биће предмет квалитативне лингвостилистичке анализе. Хоубново јединствено виђење односа културе у време писања романа и постапокалиптичне цивилизације главног јунака представљено је специфичним спелингом и отуда је анализа графостилема неопходна. Наиме, енглеским језиком овог романа никада се није говорило ни писало, јер је та верзија у овом делу доживела трансформацију од усмене легенде до фиктивног графолекта. Циљ рада је опис употребљених поступака са посебним освртом на нестандардни правопис. Закључак се бави одређивањем ефеката Хоубнове „реформе” и њеног доприноса књижевноуметничкој вредности романа.

Кључне речи: графостилеме, ортографија, интерпункција, спелинг, приказ текста, графолект, Ридли Вокер.

*ipalibrk@gmail.com

** Рад је урађен у оквиру пројекта Динамика структура савременог српског језика, бр. 178014. 


\section{І УВОД}

Аутор дела које обрађујемо широј књижевној критици мање је познат или, боље речено, познатији је критичарима дечје књижевности, пошто већи део његовог опуса припада управо том жанру. Ипак, његова селидба са једног континента на други кулминирала је променом жанра, а можда су му професионална и лична зрелост допустиле да се опроба у нечему другачијем. Од тада га доводе у везу са Волтером Милером, Френком Хербертом, Виљамом Бароузом и Ентонијем Бурџисом, пре свега због тема, мотива и појединих средстава које користи ${ }^{1}$. Његова визија будућности и прогреса људске врсте свакако је обојена делима поменутих претходника, а у многоме се подудара и са оном приказаном у „Господару мува” Виљама Голдинга. Дакле, роман припада жанру научне фантастике и како можемо сазнати на пишчевој интернет страници, награђен је два пута ${ }^{2}$. Главног јунака и наратора поједини упоређују са Хаклберијем Фином и Стивеном Дедалусом, али мишљења о квалитету и успеху подухвата су опречна. Већина се слаже у томе да је Хоубново поигравање језиком ако не оригинално, бар одлична идеја. Опште су познати разлози сличних иновација у романима модернизма и свих каснијих покрета, али овде имамо пример несвакидашњег виђења значаја писане речи. То истицање значаја писане речи критици, књижевности и нама лингвистима није страно, али је занимљив начин који савремени писац бира да повеже језик, будућност и (суноврат) цивилизације и то не на основу познавања дијахронијске лингвистике. Много о пишчевим изборима сазнајемо у предговору, поговору, белешкама и глосару с краја романа, као на пример и чињеницу да се овим проблемом бавио пет година, ревидирао више пута и петсто страна свео на двеста двадесет. Бројке иду у прилог квантитету, а писац предговора сматра да је овакав поступак суштина модерног идентитета и да је „фонетска сировост” Ридлијеве ортографије управо његова борба са недовршеним писаним језиком, чиме се захтева да читалац чини исто (Хоубн 2002: іх). Поменуте супротне ставове о спорним питањима вероватно је најбоље сумирао професор Мален у својој студији где износи да језик романа није у потпуности произвољна творевина, а да се евентуална мањкавост огледа у недостатку уверљивих објашњења како су могући поједини описани догађаји (Мален 2000: 392). С друге стране, то се може односити на припадност романа жанру научне фантастике, а ми се тиме овде нећемо бавити.

Оно што морамо напоменути у циљу бољег разумевања контекста јесте да се читаоцима приказује живот једне заједнице у данашњој југоисточној Енгеској у неодређеној будућности, отприлике два миленијума од времена објављивања. У питању је пост-нуклеарни период у коме је сва технологија

\footnotetext{
${ }^{1}$ https://www.goodreads.com/book/show/776573.Riddley_Walker, преузето 05.10.2018.

${ }^{2}$ https://www.russellhoban.org/title/riddley-walker, преузето 05.10.2018.
} 
сведена на ниво Гвозденог доба. Номадски начин живота становника и њихова култура представљени су као примитивни, а наратор, Ридли Вокер, дванаестогодишњи је дечак који настоји да сазна нешто више о историји свог народа и покушају да се он врати на пређашње, по свему судећи, напредније стање. Такође, пред нашим се очима одвија и његово сазревање и преображај од првог обреда иницијације, преко осталих за описану цивилизацију устаљених форми, до последњег ступња адаптације правилима друштва и схватања сопствене улоге и места у њему. Аутор нас промишљено враћа, скрећући пажњу на језик, или оно што је од њега (п)остало, успоравајући процес читања, тако да у темпоралном смислу, заједно са Ридлијем почињемо да разумемо поредак датог фиктивног света. Тамо владајућа структура живи на острву Рам (претпоставља се данашњи Рамзгејт, који није острво, али је то постао после нуклеарне катастрофе). О њима знамо веома мало, осим да су образовани и баве се научним истраживањима. Шаљу на копно своје представнике и неку врсту војника који сакупљају порез и преносе нове одлуке или законе: Прај Минсера (алузија на премијера и игра речима) и Вес Минсера (алузија на Вестминстер, седиште Владе), а једна од њихових дужности је да у виду луткарске изведбе препричавају стално променљиву историју Јуса. Ридли је припадник групе која сакупља храну или надничи на некој од Владиних фарми, син „везног човека”, неке врсте проповедника чији је задатак да објасни или протумачи групи значење представа. Они су једини писмени, а једино писано дело које се помиње је Јусина Прича, нешто налик Светој књизи, написана „старим писмом”. Ридли пише „новим писмом”, а постоји и одељак Легенда о св. Јевстатију, написан стандардним енглеским, који јунаци не разумеју, а који покушавају да растумаче. Тако се упознајемо са „Ридлиговором”, како га са̂м аутор назива у поговору и речнику, уз објашњење како је настао - углавном пишчевом игром. Свакако се намећу питања: 1) како су син и отац описмењени, 2) шта су читали ако је остатак света заједно са институцијама образовања у рушевинама, 3) како Ридли пише своју причу без сусретања са примерком књиге (а све се остало преноси усменим путем), и 4) која је функција „поломљеног језика” (опет пишчев назив) у приказивању прилично мрачне судбине цивилизације и писмености коју ће „превише науке” одвести у пропаст. Међутим, Ридлијев поломљени или често једноморфемски језик последица је или нужни ефекат нуклеарне катастрофе, тј. упрошћено и банализовано - ломљења атома, процеса 1 Bigl, како се у роману зове, те су и речи његовог језика „само” атоми. 


\section{II АНАЛИЗА}

На почетку овог дела дозволићемо себи клише да „слика говори хиљаду речи", јер сматрамо да је у овом специфичном случају најбоље пре предложене анализе визуелно приказати почетак и илустровати како заправо изгледа језик - „Ридлиговор”, предмет овог рада.

Слика 1. Ридли Вокер, 2002, страна 1.

On my naming day when I come 12 I gone front spear and kilt a wyld boar he parbly ben the las wyld pig on the Bundel Downs any how there hadnt ben none for a long time befor him nor I aint looking to see none agen. He dint make the groun shake nor nothing like that when he come on to my spear he wernt all that big plus he lookit poorly. He done the reqwyrt he ternt and stood and clattert his teef and made his rush and there we wer then. Him on 1 end of the spear kicking his life out and me on the other end watching him dy. I said, 'Your tern now my tern later.' The other spears gone in then and he wer dead and the steam coming up off him in the rain and we all yelt, 'Offert!'

The woal thing fealt jus that littl bit stupid. Us running that boar thru that las littl scrump of woodling with the forms all roun. Cows mooing sheap baaing cocks crowing and us foraging our las boar in a thin grey girzel on the day I come a man.

Оно што је одмах видљиво и непознаваоцима енглеског језика јесу бројне неправилности у тексту. Чак из првог пасуса да̂ се наслутити пишчева намеравана поента - да што веродостојније прикаже једну могућност - како изгледају фрагменти колективне свести (Хоубн 2002: vii) разбијене у парампарчад, или да будемо ближи контексту радње - дигнуте у ваздух. Колико је у томе био успешан може се утврдити и на основу анализе графолошког нивоа „Ридлиговора”. Роман у оквиру Легенде о св. Јевстатију на стандардном енглеском садржи око петсто речи, „старо писмо” има шест пута више, а остатак је исписан „новим писмом”, Ридлијевим (што је око осамдесет хиљада речи). Занимљиво је да је око сто форми заједничко свим писмима, три су исте у стандарду и старом, а разликују се у новом (претпоставља се с намером да покажу звучне промене), притом једна није доследно спроведена (Мален 2000: 393). 
Пошто се ради о покушају фонетске траскрипције, односно Ридли пише како говори и чује, можемо приметити неколико промена у односу на стандард, али не увек и на одређене варијете - нпр. говор јужне Енглеске, Кокни, амерички. Како је британски енглески дијалекат у коме се $/ r$ / иза вокала на крају речи не изговара, очекивано би било да се то $-r$ и не пише него замени вокалом - $a$, али то није случај. Од осталих промена јављају се:

a) упрошћавање сугласничких група на крају речи, тако да се последњи сугласник никада не изговара $/ n d>n /, / l d>l /, / k t, s t, n t, f t, p t>k, s, n$, $f$, и $t /$ као у foun [found], tol [told], kep [kept], shif [shift];

б) замена сугласника (услед једначења или дијалекатски) - $/ d>t, \underline{\partial} / \underline{\theta}$ $>v$ или $f$ осим у функцијским речима, замену гласова $/ n / \mathrm{n} / \mathrm{m} /$, нпр. y helt [held], breave [breathe], teef [teeth], emminy [enemy], bargam [bargain];

в) додавање гласа $/ n /$ испред вокала (претпостављамо остаци неодређеног члана), али не свуда већ само у речима које садрже још неко $/ n /$, што налазимо у nindicater [indicator];

г) пермутовање вокала и гласа $/ r /$ после плозива, као у pirnt [print], exter [extra], kirstel [crystal];

д) уметање гласа $/ r /$ тамо где се у енглеском и иначе јавља, нпр. userel [usual];

ђ) губљење ненаглашеног слога, попут mincer [minister], delkit [delicate], plittical [political], member [remember], што се и у данашњем говору многих дијалеката дешава, односно чује.

Детаљни попис промена и исцрпна објашњења дати су у раду „Дијалект, графолект и прича: Хоубнов Ридли Вокер и научна фантастика" (Мален 2000: 394-395), али ми се овде усредсређујемо на графолошки ниво.

Што се система писања тиче, вратимо се на фразу из наслова енглески по Вуку - наиме, у оба језика, српском и енглеском, фонологија и графологија нераскидиво су повезане. Док у данашњем енглеском јединице алфабетског система релативно успешно приказују гласове (Палибрк 2017: 180), у „Ридлиговору”, својеврсној модификованој верзији, не служе као предлог реформе. Овде су више пишчева визија будућности, знак деконструкције и реконструкције друштва, а самим тим и језика - његов став о „политици прогреса” која се неминовно одражава и на језик. Из тога следи да се горенаведене фонолошке промене морају огледати у спелингу. Из лингвистичке перспективе, можемо расправљати о веродостојности и доследном спровођењу, историјској заснованости и вероватноћи, али практично и у контексту датог фиктивног света - ова је верзија врло функционална, ма колико напора у дешифровању захтевала. Опет наглашавамо, једна од функција и јесте да нас као читаоце стави у исту раван са дванаестогодишњим приповедачем и његовим покушајем да разуме 
поредак и стање света у ком се налази. У делу који следи наводимо примере најбројнијих ортографских промена које смо успели да забележимо.

1) Писање самогласника:

- д дифтонг /әซ/ углавном као оa осим ако се налази на почетку, у пар речи је $o$, на крају као ow-only, boan [bone], boath [both], poast [post], know;

- /aø/ као ow - sowt [south], prowd [proud], trowsers [trousers];

- /aI/ се пише словом у и кад мења $i$, ie, ig, igh-clym [climb], wyld [wild], myt [might], syn [sign], sy [sigh];

- /eI/ најчешће као ay - chaymber [chamber], playg [plague], wayst [waste], wayt [wait];

- /ог као oy - poysen [posion], royl [royal], noys [noise];

- дуги вокал /i:/ пише се словима ea - feal [feel], kean [keen], keap [keep];

- /u:/ као $u$-frute [fruit], luce [loose];

- /a:/ као ar-larf [laugh], marst [mast];

- /o:/ као aw-becaws [because], cawt [caught], paws [pause];

- неми вокали се изостављају - befor [before], little [little], али не и у именицама.

2) Писање сугласника:

- финално on замењује се финалним ing - millying [million], lessing [lesson];

- елизије финалних сугласничких група у именицама, најчешће кад се јавља више од два сугласника - nex [next], strenth [strength];

- гласови / t $\int, \mathrm{d} 3, \int, 3 /$ пишу се како и иначе, осим у пар изузетака - rayj [rage], Chaynjis [changes];

- финална сугласничка група nce пише се како се и чује $n t s-d a n t s$ [dance], fents [fence];

- иницијално qu словима $q w$, (што је у поређењу са свим претходним примерима недоследно, јер се чује $/ \mathrm{kw} /$; одн. имамо интерно одступање од задатог узуса) - qwyet [quite], sqware [square];

- удвајање звучних сугласника када им претходи кратак самогласник - rivver [river], clevver [clever], crummelt [crumbled].

3) Раздвајање сложеница

Све сложенице се деле на по две речи.

- функцијске речи и везане морфеме, неодређене заменице, упитне речце, повратне заменице - anyl, her self, some times;

- $\quad$ кад иницијално $a$ или $е$ које се изговара /ə/ није наглашено - a sleap [asleep], a rive [arrive], a nuff [enough], all mos [almost]; 
- морфеме an- или en- постају and, ex- иду у as, in- и en- у in - and til [until], and tirely [entirely], as site [excite], as plain [explain], in joy [enjoy];

- предлози и прилози - unner neath [underneath], for ever [forever], to gether [together]; али не када се творе прилози - acrost [across], amongst [among], beside.

Необјашњивим се чине две појаве раздвајања у de vyd [devide] и vy brations [vibrations], пошто нису сложенице. Можемо једино претпоставити да писац ствара нову морфему од комбинације фонема $v y$-. Више о морфолошким (и синтаксичким) онеобичењима налазимо у већ поменутом раду (Мален 2000: 399-401), а такође и у „(Не)преводиво у роману Расела Хобана Ридли Вокер” (Тошић Лојаница 2017: 111-114).

4) Примећено је и произвољно или најпре креативно писање појединих речи да се покаже неразумевање јунака̂ или њихова погрешна интерпретација појединих техничких термина из периода пре нуклеарне катастрофе, што се заправо илуструје играма речи, а ефекти су често комични - axel rate [accelerate], barren year [barrier], common nations [communications], come plaining [complaining], gallack seas [galaxies], low cations [locations], res and due [residue], stablisht men [establishment], tack ticks [tactics], the qwipt man [equipment].

5) Такође имамо појаву стварања сложеница, посебно у властитим именицама и неологизмима са јасним конотацијама или сатиричним ефектима - Goodparely (<good+parler - елоквентни), Slymouf (<sly+mouth - лукави, препредени говорник), Belnot Phist ( $<$ Nobel + physicist - физичар нобеловац, а презиме се исто изговора као и fist - песница), поменути Pry Mincer ( $<$ Prime Minister - премијер; значење глагола pry је вребати, забадати нос, а mince је пренемагати се, али и самлети месо), са̂м наратор Riddley Walker (<riddle+walk - онај који решава загонетке и онај који хода).

6) Писање бројева и појединих назива увек је и искључиво изведено цифрама - 1 Big 1, 1/2, 2 weals 4 men inside [two wheels for men inside].

Свакако се слажемо са оценом да је лексички ниво најпогоднији за иновације и бројна експериментисања (Тошић Лојаница 2017: 113) и на формалном и на семантичком плану.

Што се интерпункције и приказа текста тиче, маркирана је неупотреба запета у сложеним реченицама. Мисли се нижу и одвајају везницима, а запета служи да уведе индиректни говор. Тако је поједине реченице, поготову оне које изражавају ток мисли, тешко пратити. Апострофи се у скраћеним облицима помоћних глагола никада не бележе. 
Међутим, занимљива је употреба наводника у директном говору и уопште сегментација. Роман је подељен на поглавља, она на пасусе, јављају се дијалози уобичајени за роман, фолклорне песме (јасно одвојене и подељене у стихове), нумерисане листе. Пошто су ово уобичајени поступци манипулисања текстом у прози, шта је спорно? Премда је оваква ситничавост више у вези са питањем литерарне конструкције, морамо да приметимо - ако Ридли не чита књиге јер оне не постоје, како је могуће да своју причу исписује на овакав начин у периоду од две недеље и без претераног промишљања. Ипак, постоји логично објашњење: аутор је највероватније сматрао да би гушћа графостилемска форма одвратила читаоце од даљег декодирања текста, а и уреднику посао је био умногоме отежан (што Хоубн и наводи у поговору). И курзив се користи у називима и емфази, те опет можемо да питамо откуд он у Ридлијевом огољеном графолекту. Или нпр. фуснота? Нико ко живи у искључиво усменој традицији не може да измисли поступке сегментације или интерпункцијске знаке и не могу се појавити ни од куда (Бјуглер 2000: 411). Осим уколико књижевност предложене културе није успостављена чвршће него што се да̂ закључити из текста. У сваком случају, одабир интепрункцијских знака показује прозодијске одлике новог језика нашег романа и у том смислу они су функционални. Евентуалне недоследности ортографије и интерпункције могу се приписати умећу младог наратора, особинама наративног тока који је најсличнији разговорном стилу и на крају, мањим техничким омашкама. Идеја и смелост у спровођењу несумњиво су вредни хвале, а недоумице ћемо оставити критичком пуризму. Приказ текста је последица и техничких могућности и пишчеве умерености - другачији избори резултирали би знатно већим напором при читању и разумевању, а у крајњој мери и нечитљивости.

У роману се од осталих графоелемената јављају: мапа Инленда на почетку (стр. хvii), две једноставне илустрације појмова који се у датом тренутку описују (43. и 160. страна), слика фреске Легенда о св. Јевстатију из кантерберијске катедрале (222. страна) и скица марионете Панча на крају (стр. 232), сви контекстуално и ванконтекстуално повезани са самом причом. Писац и издавач могли су себи да допусте и овакве елементе у изразито графостилемски маркираном роману.

\section{III ДИСКУСИЈА}

Ридли Вокер се може анализирати и на осталим нивоима стилске анализе, те можемо говорити о религијским мотивима, митским обрасцима, идеологији и политици, односно критици друштва, науке и технологије, о научној основи приказаног, прихватљивости понуђене верзије. Лингвостилистички гледано, понуђени графолект није новина, али само уколико дозволимо поређење са 
правом фонетском транскрипцијом, каква постоји у српском, на пример. Ипак, имамо у виду да се 44 фонеме енглеског пишу на преко 1100 начина и да су те комбинације стваране вековима. Знамо колико је времена писац провео бавећи се овим романом и да је издавачкој кући, уреднику и коректору он представљао огроман подухват. Разумевање редукованије верзије графолекта просечном читаоцу енглеског језика било би готово онемогућено, а то значи улагање прекомерног труда за читање дела чија је примарна функција естетска. Волтер Онг у „Усмености и писмености” тврди да је писање одавно заменило „усменост”, али и да се са текстуалношћу интернета јавља „друга усменост”. Дакле, усменост културе непомућене познавањем писма и писања или штампе он сматра примарном, док је усменост данашње секундарна. Чисто усмену традицију није више лако ни замислити исправно, јер управо писање чини да речи изгледају као предмети о којима размишљамо као о видљивим ознакама: речи у текстовима и књигама ми можемо да видимо и додирнемо (Онг 2012: 8-11). Без писања, људски ум не би умео ни могао да мисли као што то чини, јер је писање више од било ког другог изума трансформисало људску свест. Склањањем речи из света звука одакле су потекле и њиховим размештањем на визуелну површину, као и експлоатисањем те површине на десетине начина, штампа нам је омогућила да о унутрашњим свесним и несвесним елементима размишљамо као о предметима (Онг 2012: 49).

Даље, нама данас и није толико тешко да растумачимо „Ридлиговор”, јер поступке овде коришћене сами користимо свакодневно. Развој комуникационих технологија довео је до стварања трећег медија између говора и писања, па оно што су 1980. биле иновације и онеобичења можемо назвати неуспелим покушајем. Субјективност на страну, роман је награђен и хваљен у круговима поштовалаца жанра и људи од пера, а из лингвистичког угла проблем не представљају ни минорне недоследности ни неоправданост поступака. То је могуће у језику и језиком направити, али појединима утисак негирања или непознавања језичке промене умањује сјај. Да цитирамо аутора:

Јочи на почетку језик је почео да клизи ка Ридлиговору; ја волим да се играм звуцима, и сам код куће говорим чудним акиентима користећи нонсенсе. Пропадағе граматичког нивоа почело је избацивањем помоћног глагола у садашьем перфективном времену - много деце са којом сам ишао у школу у Пенсилванији говорило је тако [...] Једно је водило ка другом и дијалекат који сам добио на крају мени се у потпуности чини вероватним, језик не мирује и речи често носе давно заборављена значења. Ридлиговор је пуко кварење и извртање стандардног енглеског, тако да би читалаи који изговори речи и употреби мало маште морао бити способан да га разуме. Технички, слаже се са причом јер успорава читаоца до Ридлијеве брзине разумевања. (Хоубн 2002: 225)

Технички, аутор није лингвиста и практично не мора да буде. Бјуглер сматра да Хоубн мора знати да се језици не кваре, те разлика између стан-

\footnotetext{
${ }^{3}$ Превод наш.
} 
дардног енглеског и „Ридлиговора” није последица деградације или кварења нити сме то да одсликава. Може бити последица протока времена, али како би он изгледао кроз две хиљаде година ми не можемо да утврдимо, али можемо да претпоставимо да би био непрепознатљив и потпуно неразумљив говорницима са истог географског подручја (Бјуглер 2000: 416). Примери су бројни како у историји српског, енглеског тако и других језика, а можда је најбољи пример латинског и свих језика који су од њега настали. Међутим, сматрамо да је оригиналност идеје неоспорна, а томе иде у прилог чињеница да „Ридли Вокер” и после четрдесет година није преведен на српски језик, јер се још увек није нашао преводилац довољно стрпљив и смео да комплетира процес постизања културолошке, лингвистичке и експресивне еквиваленције у преводу (Тошић Лојаница 2017: 118).

Енглески правопис могао је да ревидира спелинг тако да рефлектује гласовне промене које су се дешавале раније, али се то није догодило, што је променило однос енглеског писма и изговора. Од релативно једноставног односа фонеме и графеме до времена модерног енглеског, све чешће постаје неопходно да се зна која се морфема пише. Зато у данашњим енглеским речима постоји велики број случајева да је спелинг морфофонемски или морфемски. Већина речи које су у енглески дошле из других језика задржала је оригинални спелинг, а изговор позајмљенице се мењао да би се уклопио у модел енглеског (Роџерс 2005: 190-192). Услед сложене релације између писања и говора до сада је било више предлога реформе спелинга и имали су за циљ да се енглески пише тако да је сваки глас представљен једним симболом, а једини начин да се то и постигне јесте укидање морфемске хетерографије. Упркос бројним настојањима да до реформе дође, од идеје се одустало, пре свега због квантитета постојећег писаног материјала (Роџерс 2005: 195-197).

\section{IV ЗАКЉУЧАК}

Писаног материјала у Инланду, како смо сазнали, нема уопште или бар Ридлију није доступан, али управо ту лежи одговор не на питање како он пише своју причу, већ на питање зашто је пише. Објашњење је једноставно, као он са̂м, као језик којим говори и пише - свевременска потреба да за собом остави траг. Хоубнов графолект не представља стварни графолект неког будућег енглеског али је једно од средстава које причи даје оквир. На крају, да ли уопште треба да га оцењујемо према оквирима лингвистичких норми савременог енглеског језика? Стилистички гледано, територије контекста и избора прилично су „клизаве”. А тек на територији фикције, могуће и немогуће узалуд се боре. Пишчева дисторзирана верзија постиже ефекат тематског обогаћења, „отвара врата прошло-будућег света, и зато је важно да 
га разумемо, јер на тај начин допиремо до суштине Ридлијеве приче" (Тошић Лојаница 2017: 117). Знамо да говорници адаптирају језик својим потребама, а напуштање и поновно реконструисање појединих речи у „Ридлиговору” не показује да је језик пропао или мутиран, само другачији од нашег. Дело је сложено и вишеслојно, а Расл Хоубн је специфичним спелингом успешно представио виђење историје, друштва, улоге језика и културе свог времена и постапокалиптичног света свог јунака и засигурно овим поступком позитивно утицао на укупну књижевноуметничку вредност романа.

\section{ИЗВОРИ:}

a) Расл Хоубн - R. Hoban, Riddley Walker, London: Bloomsbury, 2002.

б) сајтови чије су адресе и датуми преузимања наведени уз примере.

\section{ЛИТЕРАТУРА}

Бјуглер 2000: T. Bugler, „Ten years after: Four responses to R. D. Mullen”, Science Fiction Studies, vol. 27, n. 3, Indiana State University: JSTOR, p. 411-416.

Мален 2000: R. D. Mullen, „,Dialect, Grapholect, and Story: Russell Hoban's Riddley Walker as Science Fiction", Science Fiction Studies, vol. 27, n. 3, Indiana State University: JSTOR, p. 391-406.

Онг 2012: Walter J. Ong, Orality and Literacy - The Technologizing of the Word, London and New York: Routledge.

Палибрк 2017: И. Палибрк, Карактеристични графостилемски поступщи у модерној англоамеричкој и српској књиюевности, докторска дисертација, Крагујевац: ФИЛУМ, Универзитет у Крагујевцу.

Poџepc 2005: Henry Rodgers, Writing Systems - A Linguistic Approach, Malden: Blackwell Publishing.

Тошић Лојаница 2017: Т. Тошић Лојаница, (Не)преводиво у роману Расела Хобана Ридли Вокер, Крагујевац: Наслеђе 36, Крагујевац, 109-120. 


\title{
SPELL IT AS YOU SAY IT - THE GRAPHOSTYLEMIC ASPECT OF THE NOVEL RIDDLEY WALKER
}

\begin{abstract}
Summary
This paper presents the graphological level of Russell Hoban's novel Riddley Walker and the subject of our qualitative linguostylistic analysis is the author's suggested orthographical form. As his unique view on the relationship between the culture of his and the post-apocalyptic civilization of his protagonist's time is reflected in the peculiar spelling, this type of graphostylemic research seems inevitable. The aim is to describe the devices employed with regard to the nonstandard orthography. The first section introduces the author and the plot and the next one gives the detailed list and explanations of the created graphostylemic features. In the third part we discuss the presented and the interpretation problems that might occur. Finally, the conclusion deals with the effects and overall artistic value.
\end{abstract}

Key words: graphostylemes, spelling, punctuation, text presentation, grapholect, Riddley Walker.

Ivana B. Palibrk 